Jurnal Penelitian dan Pengabdian Kepada Masyarakat Bidang ilmu Pendidikan

\title{
Peranan Pemberdayaan Kesejahteraan Keluarga (PKK) dalam Meningkatkan Pemberdayaan Perempuan di Desa Matua Kecamatan Woja Kabupaten Dompu
}

\author{
Mulyati $^{1}$, Yeye Suhaety ${ }^{2}$ \\ 1,2 Program studi Manajemen, STIE Yapis Dompu, Nusa Tenggara Barat, Indonesia \\ E-mail corresponding: yhatisweet19@gmail.com
}

Article History: Received: 2021-07-22 || Revised: 2021-07-28 || Published: 2021-08-31

Sejarah Artikel : Diterima: 2021-07-22 || Direvisi: 2021-07-28 || Dipublikasi: 2021-08-31

\begin{abstract}
Family (PKK) in Improving Women's Empowerment in Matua Village, Woja District, Dompu Regency". This study aims to determine the performance of the Family Welfare Empowerment Team (PKK) in the process of empowering women in Matua Village, Woja District, Dompu Regency. The method used is interview, observation and documentation. The primary data used in this study was obtained from the Matua Village office and obtained from direct interviews with the PKK Mobilization Team. From the results of the analysis that has been carried out, it can be concluded that the Role of Family Welfare Empowerment (PKK) in Improving Women's Empowerment in Matua Village has been carried out quite well and has played a significant role in Community Empowerment which has looked quite good from empowering life skills in the form of guidance and skills, conducting training, as well as doing marketing.
\end{abstract}

Keywords: Empowerment, Family Welfare, Women.

\begin{abstract}
Abstrak
Penelitian ini merupakan penelitian deskriptif kualitatif dengan judul "Peranan Pemberdayaan Kesejahteraan Keluarga (PKK) Dalam Meningkatkan Pemberdayaan Perempuan Di Desa Matua Kecamatan Woja Kabupaten Dompu". Penelitian ini bertujuan untuk mengetahui kinerja Tim Penggerak Pemberdayaan Kesejahteraan Keluarga (PKK) dalam proses pemberdayaan perempuan di Desa Matua Kecamatan Woja Kabupaten Dompu. Metode yang digunakan adalah wawancara, observasi dan dokumentasi. Data primer yang digunakan dalam penelitian ini di dapat dari kantor Desa Matua dan didapatkan dari hasil wawancara langsung dengan Tim Penggerak PKK. Dari hasil analisis yang telah dilakukan dapat disimpulkan bahwa Peranan Pemberdayaan Kesejahteraan Keluarga (PKK) Dalam Meningkatkan Pemberdayaan Perempuan di Desa Matua telah terlaksana dengan cukup baik dan sangat berperan dalam Pemberdayaan Masyarakat yang sudah terlihat cukup baik dari pemberdayaan life skill berupa bimbingan dan keterampilan, mengadakan pelatihan, serta melakukan pemasaran.
\end{abstract}

Kata kunci: Pemberdayaan, Kesejahteraan Keluarga, Perempuan.

\section{PENDAHULUAN}

Keluarga merupakan suatu kelompok yang menjadi bagian dalam masyarakat. Keluarga terdiri dari kesatuan orang-orang yang berinteraksi dan berkomunikasi menciptakan peranan sosial. Kumpulan dari keluarga akan membentuk suatu lapisan masyarakat dan selanjutnya lapisanlapisan masyarakat tersebut akan bergabung dalam kelompok besar menjadi suatu bangsa. Baik buruknya suatu bangsa tergantung pada pembinaan anggota keluarga dan generasi yang akan datang. Dalam keluarga sendiri terdiri dari ayah, ibu, dan anak, salah satu yang berperan dalam membina keluarga adalah ibu. Sebagai seorang wanita, ibu dituntut juga untuk mempunyai waktu yang lebih lama untuk tinggal dirumah dibandingkan dengan laki-laki, dengan demikian, maka wanita dituntut untuk dapat mengatur kehidupan rumah tangganya, terutama dalam fungsi sebagai pengasuh anak dan pengatur konsumsi makanan dalam satu keluarga. Dalam membina keluarga ini, wanita memerlukan bekal pendidikan dan pengetahuan, Perkembangan menunjukkan bahwa sesungguhnya wanita mempunyai potensi yang sama besarnya dengan potensi pria, karena itu dapat dikerahkan dalam pembangunan. Secara hukum wanita Indonesia berpeluang sama dengan pria/lakilaki untuk berpartisipasi dalam proses pembangunan di semua bidang kehidupan. 
Menurut UU No. 20 Tahun 2008 tentang prinsip dan tujuan pemberdayaan, pemberdayaan yaitu bertujuan dalam rangka meningkatkan ekonomi kerakyatan agar dapat meningkatkan pendapatan dan kesejahteraan masyarakat serta memperluas lapangan pekerjaan untuk pengentasan rakyat dari permasalahan kemiskinan, menurut Pasal 21 dan pasal 27 Undang-Undang Dasar 1945 menjamin adanya kesamaan hak dan kewajiban bagi penduduk tanpa membeda-bedakan apakah pria ataupun wanita, dalam bidang bidang pekerjaan, kesehatan, politik, dan hukum, serta hak perorangan. Wanita, sebagai warga Negara maupun sebagai sumber insani bagi pembangunan mempunyai hak, dan kewajiban serta kesempatan yang sama dengan pria disegala bidang kehidupan bangsa dan dalam segenap kegiatan pembangunan.

Menurut sejarahnya, PKK semula merupakan akronim dari Pendidikan Kesejahteraan Keluarga yang bertujuan untuk melibatkan partisipasi wanita melalui program pendidikan perempuan. Kemudian, pada tanggal 27 Desember 1972 organisasi tersebut berubah nama menjadi "Pembinaan Kesejahteraan Keluarga" yang bertujuan untuk membina dan membangun keluarga dibidang mental, spiritual dan fisik serta peningkatan mutu pangan, sandang, kesehatan, dan lingkungan hidup. Anggotanya adalah tokoh/pemuka masyarakat, para isteri Kepala Dinas dan isteri Kepala Daerah sampai dengan tingkat Desa dan Kelurahan yang kegiatannya didukung dengan Anggaran Pendapatan dan Belanja Daerah, sedangkan menurut Kumolo (2017) sendiri sebagai menteri dalam negeri, dalam siaran persnya yang berjudul "PKK Punya tugas penting Gerakan potensi Masyarakat" di Jakarta, juga menyoroti soal peran PKK. Menurutnya, PKK bisa menjadi pihak di garda depan dalam mengatasi berbagai persoalan yang terjadi ditengah masyarakat. Misalnya, menggerakan ibu-ibu, bagaimana caranya menekan angka kematian ibu hamil. Atau berkontribusi mengatasi masalah gizi anak serta kesehatan anak dan stunting (kondisi gagal pertumbuhan pada anak/pertumbuhan tubuh dan otak akibat kekurangan gizi dalam waktu yang lama).

Dari sisi programnya, PKK pada awalnya diarahkan untuk mendorong kemajuan wanita agar dapat memainkan peran gandanya secara baik, yaitu sebagai pengelola keluarga, pencari nafkah dan pelaku pembangunan. Akan tetapi sesuai dengan perkembangannya, program pemberdayaan wanita kemudian diarahkan untuk mewujudkan kemitrasejajaran antara pria dan wanita dalam kehidupan berkeluarga, bermasyarakat, berbangsa dan bernegara. Dengan demikian sasarannya ditujukan untuk mengembangkan dan mengangkat berbagai potensi yang ada pada diri wanita yang memungkinkan dirinya dapat memanfaatkan hak dan kesempatan yang sama terhadap sumber pembangunan.

Kesejahteraan keluarga menjadi tujuan utama PKK. Hal ini dikarenakan keluarga merupakan unit terkecil masyarakat yang akan berpengaruh besar terhadap kinerja pembangunan dalam mendukung program-program pemerintah. Dari keluarga yang sejahtera ini, maka tata kehidupan berbangsa dan bernegara akan dapat melahirkan ketentraman, keamanan, keharmonisan, dan kedamaian. Dengan demikian, kesejahteraan keluarga menjadi salah satu tolak ukur dalam pembangunan dengan program -program pemerintah. PKK menjadi gerakan untuk membantu dan mendukung program-program pemerintah dengan mendata beberapa aspek yang diperlukan seperti data warga, ibu hamil, bayi, dan balita, kelahiran, kematian, sampai kegiatan masyarakat, PKK yang merekrut anggota sampai lapisan bawah dengan cara mengajak ibu rumah tangga yang ingin bergabung dan menjadi pengurus Organisasi PKK. Masyarakat diharapkan mampu membawa pada kondisi keluarga yang sejahtera, yaitu keluarga yang mampu memenuhi kebutuhan dasar manusia baik secara material, sosial, mental dan spiritual serta keluarga yang berdaya yaitu keluarga yang hidup sejahtera, maju dan mandiri. Melalui PKK diharapkan dapat meningkatkan pemberdayaan wanita. Pemberdayaan wanita merupakan suatu upaya untuk meningkatkan kemampuan, dan peran agar dapat melaksanakan fungsi dan peran sebagai wanita.

Selain itu, PKK diharapkan mampu membebaskan wanita dari belenggu budaya patriarkhi, sehingga memiliki kemandirian. Melalui PKK diharapkan harkat dan martabat wanita sebagai bagian dari keluarga dapat ditingkatkan. Namun, pada kenyataannya PKK belum sepenuhnya mampu merubah kondisi keluarga dan wanita, sehingga belum terwujud kesetaraan dan keadilan gender. Adanya kesenjangan ini menyebabkan perlunya melakukan penelitian terhadap PKK, khususnya di dusun selaparang desa matua, Desa Matua merupakan suatu wilayah yang terletak di Kecamatan Woja Kabupaten Dompu dengan jumlah penduduk 4.732 jiwa dan yang terdiri atas 1.382 KK (Kepala Keluarga) yang tersebar di tiga dusun diantaranya Dusun Rasanggaro, Dusun 
Selaparang Dan Dusun Buncu. Organisasi PKK di Desa Matua memiliki peranan dalam meningkatkan pemberdayaan wanita.

Berdasarkan observasi awal dan sudah mewawancarai dengan salah satu tim penggerak PKK Desa Matua, bahwa PKK yang ada saat ini tidak semaju 3 tahun yang lalu. Banyak anggota yang pasif dalam berkontribusi di kelompok PKK ini. Salah satu faktor penyebabnya karena kesibukan mengurus rumah, selain itu masih rendahnya wanita yang ikut berpartisipasi dalam melaksanakan program PKK. Program kerja yang saat ini dapat terus berjalan adalah penggalakkan KB (Keluarga Berencana), Posyandu dan PAUD. Program kerja lain seperti dalam bidang pertanian tidak lagi berjalan, karena masih sedikitnya ibu rumah tangga yang bergabung. Sistem rekruitmen kurang mempengaruhi minat ibu rumah tangga untuk ikut PKK, selain itu juga sosialisasi PKK yang masih kurang.

Dari beberapa fenomena atau uraian latar belakang yang telah dijelaskan diatas maka peneliti tertarik untuk melakukan penelitian mengenai "Peranan Pemberdayaan Kesejahteraan Keluarga (PKK) Dalam meningkatkan pemberdayaan Perempuan Di Desa Matua Tahun 2020", berdasarkan latar belakang yang telah dikemukakan di atas, Maka Rumusan masalah yang akan diangkat dalam penelitian ini, yaitu: Bagaimanakah peranan PKK dalam meningkatkan pemberdayaan perempuan di desa matua? Adapun tujuan yang hendak dicapai dalam penelitian ini adalah sebagai berikut: "Untuk Mendeskripsikan Peranan Pemberdayaan Kesejahteraan Keluarga (PKK) Dalam Meningkatkan Pemberdayaan Perempuan Di Desa Matua Tahun 2020.

\section{METODE PENELITIAN}

Jenis penelitian yang digunakan dalam penulisan skripsi ini adalah jenis penelitian yang menggunakan metode kualitatif. Menurut Sugiyono (2017:8) metode penelitian kualitatif sering disebut metode penelitian naturalistic karena penelitiannya dilakukan pada kondisi yang alamiah (natural setting), disebut juga sebagai metode etnographi, karena pada awalnya metode ini lebih banyak digunakan untuk penelitian bidang antropologi budaya, disebut sebagai metode kualitatif, karena data yang terkumpul dan analisisnya lebih bersifat kualitatif, sedangkan Sumber data menurut Zuldafrial (2012:46) adalah subjek dari mana data diperoleh. Untuk memperoleh data dalam penelitian diperlukan kesesuaian antara kebutuhan informasi yang berkaitan dengan sumber data penelitian. Beberapa sumber data yang akan dimanfaatkan dalam penelitian ini sebagai berikut: Data Primer, Data sekunder, penelitian ini peneliti menggunakan teknik pengumpulan data dengan cara observasi, wawancara, dokumentasi, angket dan studi literatur. Observasi, Wawancara, Dokumentasi, Menurut Indrawan dan Poppy (2014: 139) teknik pengumpulan data melalui studi dokumentasi diartikan sebagai upaya untuk memperoleh data dan informasi berupa catatan tertulis atau gambar yang tersimpan berkaitan dengan masalah yang diteliti. Pengumpulan data dengan cara dokumentasi merupakan suatu hal yang dilakukan oleh peneliti guna mengumpulkan data dari berbagai hal yang dibahas dengan narasumber yang akan diteliti, sedangkan Teknik analisis data yang digunakan mencakup tiga kegiatan yaitu sebagai berikut: Reduksi Data, Pengujian Data, Penarikan Kesimpulan.

\section{HASIL DAN PEMBAHASAN}

\section{A. Analisis Data}

Setelah peneliti mengumpulkan data hasil penelitian yang diperoleh dari hasil wawancara/interview, observasi, serta dokumentasi maka selajutnya peneliti akan melakukan analisis data untuk menjelaskan lebih lanjut dari penelitian. Sesuai dengan analisis data yang dipilih oleh peneliti yaitu menggunakan analisa studi kasus dengan suatu kajian peristiwa yang mendalam di lingkungan, dan kondisi yang memungkinkan mengungkapkan dan memahami peristiwa sesuatu yang berkaitan dengan program Pemberdayaan Kesejahteraan Keluarga (PKK) hingga mampu mangatasi masalah kemiskinan dan mampu mengembangkan Potensi yang dimiliki oleh perempuan.

1) Pemberdayaan Kesejahteraan Keluarga dalam hal Pemberdayaan Life Skill

a) Keterampilan Memasak

Keterampilan memasak merupakan program kerja (pokja) II Pemberdayaan Kesejahteraan Keluarga (PKK) Desa Matua. Keterampilan memasak dilakukan pada saat pertemuan rutinitas PKK setiap bulannya, keterampilan memasak terdiri dari beberapa kegiatan, anataralain: 
pembuatan kue bolu, pembuatan keripik, kue basah, dan Lain-lain. Proses pemberdayaan keterampilan memasak sama seperti kegiatan keterampilan lainnya antaralain: a) Bimbingan dan arahan dari ketua Pemberdayaan Kesejahteraan Keluarga (PKK), b) Pembagian kerja, c) Mengadakan pelatihan.

b) Pelatihan

Dalam melaksanakan pelatihan keterampilan memasak yang menjadi instruktur yaitu Ibu Sri Astuti yang berdomisili di Dusun Selaparang Desa Matua. Ibu Sri Astuti merupakan salah satu masyarakat di Di Desa Matua yang mahir dalam pembuatan berbagai macam kue. Ibu Sri Astuti di undang PKK untuk mempraktekkan langsung kepada ibu-ibu yang hadir dalam rangka pelatihan keterampilan memasak. Keterampilan memasak yang diterapkan berupa, pembuatan kue bolu, kue basah, dan berbagai macam keripik, dan lain-lain

c) Peserta

Peserta dalam pelatihan keterampilan memasak adalah anggota Pemberdayaan Kesejahteraan Keluarga (PKK) yang tergabung dalam organisasi PKK adapun jumlah yang mengikuti pelatihan sebanyak 20 orang.

d) Keterampilan memasak dilaksanakan setiap pertemuan rutin PKK yaitu setiap tanggal 28 . Pelatihan ini dilakukan selama 4 jam mulai dari pukul 14.00-17.00 WIB. Pelatihan keterampilan memasak dilaksanakan di Balai kantor Desa Matua.

e) Pemasaran

Pemasaran kue yang dilakukan sebelumnya ke Kios-kios, namun sekarang bentuk pemasaran kue untuk saat ini yaitu ketika adanya permintaan dari konsumen. Hasil dari pemasaran kue tersebut sebagai masukan untuk penghasilan Pemberdayaan Kesejahteraan Keluarga (PKK) yang nantinya penghasilan-penghasilan yang mereka peroleh dapat dinikmati bersama para Kader Pemberdayaan Kesejahteraan Keluarga (PKK).

Menurut Ibu salmah (37 Tahun) mengatakan bahwa: "Masyarakat sangat termotivasi dan sangat terbantu dengan adanya PKK ini, terutama bagi perempuan-perempuan yang masih mengandalkan Gaji suami mereka serta penghasilan yang belum mencukupi, Untuk hasil keterampilan memasak seperti membuat aneka jajanan kripik, dan sebagainya itu dapat dijual dan hasil penjualanyapun bisa mencukupi kebutuhan sehari-hari', Hal ini sesuai dengan apa yang dikatakan oleh ibu Siti ayisah (40 Tahun) yang mengatakan bahwa :"Kegiatan PKK pada umumnya itu untuk membantu masyarakat di Desa khususnya memberikan kemudahan dalam melakukan usaha dan untuk membantu masyarakat tak mampu, Sedangkan peran PKK itu sendiri untuk kesejahteraan masyarakat khususnya di Desa Matua menjalankan program Pendidikan Dan Keterampilan agar dapat membantu permodalan bagi masyarakat yang ingin membuka usaha", Berdasarkan hasil wawancara di atas dapat disimpulkan bahwa Pemberdayaan Life Skill atau keterampilan yang diterapkan oleh (PKK) Desa Matua selain dapat meningkatkan potensi yang dimiliki oleh perempuan, program PKK ini juga dapat membantu meringankan beban ekonomi masyarakat yang kurang mampu.

2) Pemberdayaan Kesejahteraan Keluarga dalam hal Pembinaan Rohani

Pemberdayaan Kesejahteraan Keluarga dalam hal pembinaan Rohani dilaksanakan karena adanya usulan dari Camat Woja. Pembinaan rohani ini juga memang harus dilaksanakan oleh organisasi Pemberdayaan Kesejahteraan Keluarga (PKK) Desa Matua agar adanya kegiatan pembinaan rohani ini untuk setiap bulannya. Adapun kegiatan yang dilaksanakan berupa yasinan akbar dan pengajian rutin, Berdasarkan hasil wawancara yang penulis lakukan dengan Ibu Ijnah selaku sekretaris Pemberdayaan Kesejahteraan Keluarga (PKK), mengatakan bahwa Pembinaan rohani ini di adakan setiap bulannya, dan bertepatan setiap tanggal 15, 16 sampai tanggal 17. Pengajian tersebut dilaksanakan secara bergilir di setiap Masjid yang sudah terpilih oleh Tim Penggerak PKK di setiap Dusun yang ada di Desa Matua dengan kegiatan yang dilakukan yaitu Yasinan akbar, dan pengajian rutin.

Adapun Ustadz dan Ustadzah yang di undang untuk memberikan tausiyah dalam kegiatan pembinaan rohani yaitu: Ustadz H.Mansur H.Jainuddin, dan Ustadzah Hj.Nurjannah H.Ismai, Namun kegiatan yasinan akbar dan pengajian untuk saat ini sudah mulai tidak aktif seperti biasanya. Sebelumnya pengajian diadakan sebulan sekali, sementara untuk saat ini sudah tidak 
rutin setiap bulan dilaksanakan, dikarenakan adanya factor penghambat lain yaitu kesibukan masyarakat dalam melaksanakan kegiatan lainnya, Hal ini sesuai dengan apa yang dikatakan oleh ibu Erna (35 Tahun) yang mengatakan bahwa: "Sebenarnya pemberdayaan dalam Pembinaan Rohani di Desa Matua ini sangat bermanfaat sekali bagi masyarakat justru akan menambah pengetahuan serta wawasan dalam mendengarkan kajian agama tersebut, namun sangat disayangkan bahwa untuk sekarang pembinaan rohani justru malah kegiatanya sudah tidak rutin lagi".

Berdasarkan hasil wawancara di atas dapat disimpulkan bahwa masyarakat sangat antusias dengan adanya program PKK yaitu Pembinaan Rohani tersebut tetapi sekarang dikarenakan kegiatanya sudah tidak aktif lagi seperti biasanya justru masyarakat sangat menyayangkan sekali, namun masyarakat mengharapkan bahwa kegiatanya kembali rutin lagi seperti sebelumnya.

3) Pemberdayaan Kesejahteraan Keluarga dalam hal Pemberdayaan Kesehatan

Kesehatan merupakan salah satu hal penting dalam hidup. Hal ini terkait dengan pola hidup seseorang. Bagi mereka yang selalu hidup sehat tentu harus pintar menjaga lingkungan serta dirinya. Setiap orang memiliki tugas dan kewajiban memelihara kesehatan diri serta anggota dalam keluarganya, Kesehatan merupakan salah satu program Pemberdayaan Kesejahteraan Keluarga, kesehatan termasuk dalam poin ke tujuh dari sepuluh program pokok PKK yang diterapkan disetiap jenjang. Kesehatan ini juga termasuk dalam program kerja IV PKK Desa Matua. Adapun pokja IV yang diterapkan Pemberdayaan Kesejahteraan Keluarga (PKK) Desa Matua berupa pemberdayaan kesehatan pada balita dan lansia.

Berdasarkan hasil wawancara yang penulis lakukan dengan Ibu Rosmawi selaku kader PKK mengatakan bahwa lokasi posyandu yang ada di Desa Matua sudah terbagi menjadi tiga lokasi yaitu di dusun selaparang, dusun buncu dan dusun rasanggaro. Adapun Nama posyandu yang sudah saya lakukan penelitian yaitu di dusun selaparang bernama Posyandu Mawar, Dimana kegiatan posyandu yang diterapkan Pemberdayaan Kesejahteraan Keluarga (PKK) dilaksanakan setiap bulannya, dan bertepatan setiap tanggal 6, dan dilaksanakan di setiap dusun yang ada di Desa matua. Pos pelayanan terpadu atau yang sering pula disingkat dengan Posyandu, terdapat lima layanan yang dapat di manfaatkan, Adapun lima layananan yang dapat dimanfaatkan adalah sebagai berikut: Perbaikan Gizi, Imunisasi, Penanggulangan Diare, Keluarga Berencana (KB), Kesehatan Ibu dan Anak.

Pada balita, Posyandu Mawar mengadakan penyuntikan untuk usia 0-12 bulan, dan Pemberian Makanan Tambahan (PMT) dilaksanakan dengan memberikan makanan tambahan untuk balita. Makanan tambahan yang diberikan adalah susu, bubur kacang hijau, pisang. Makanan-makanan tersebut dipilih karena mengandung gizi yang baik dan disukai oleh balita, kegiatan pemberian makanan tambahan (PMT) ini dilaksanakan setiap bulannya yaitu setiap tanggal 6, karena posyandu Mawar begitu antusias untuk memberdayakan kesehatan balita maupun lansia. Kegiatan Pemberian makanan tambahan (PMT) ini merupakan bentuk kepedulian dari Pemberdayaan Kesejateraan Keluarga (PKK) untuk menjaga asupan gizi bagi balita. Asupan gizi balita sangat penting karena baik buruknya proses pertumbuhan dan perkembangan anak tergantung dari asupan gizi. Dengan adanya program ini agar dapat memberikan pengenalan gizi kepada ibu-ibu terhadap anak-anaknya, dan supaya masyarakat lebih peduli dengan gizi sehat.

Pada lansia Posyandu Mawar mengadakan periksa kesehatan fisik para lansia dan di periksa kesehatannya oleh petugas kesehatan, baik keluhan pada saat di periksa, tekanan darah, pemeriksaan kimia darah (kolestrol, gula darah, asam urat), dan sebagainya. Posyandu lansia juga mengadakan olahraga ringan yang sesuai untuk usia mereka, Sehingga para lansia memenuhi kebutuhan aktivitas fisik mereka. Selain itu, posyandu mawar mengadakan penyuluhan mengenai pola hidup sehat bagi lansia, Menurut A (38 Tahun) menyampaikan bahwa: "Sejalan dengan perkembangan posyandu sebagaimana telah dilakukan oleh hampir seluruh daerah, melalui pengintegrasian berbagai layanan dan pelayanan yang disesuaikan berdasarkan situasi, kondisi kebutuhan masyarakat, dan budaya setempat (kearifan local). Posyandu menjadi salah satu lembaga kemasyarakatan yang memiliki potensi untuk 
dikembangkan sebagai wadah yang sangat strategis dalam menyampaikan berbagai program dan kegiatan, karena tujuan dan sasarannya bersentuhan langsung dengan masyarakat", Hal yang sama juga disampaikan oleh D (40 Tahun) bahwa: "Kondisi ini perlu terus di dorong dan difasilitasi pemerintah dan pemerintah daerah untuk dijadikan basis model pengembangan posyandu secara nasional dalam persepektif lembaga kemasyarakatan yang mampu menyediakan dan mampu memberikan berbagai layanan dan pelayanan masyarakat secara terpadu".

\section{B. Tujuan Dari Dilaksanakannya Kegiatan Pemberdayaan Kesejahteraan Keluarga Yang Terdiri Dari Pemberdayaan Life Skill, Pembinaan Rohani Dan Pemberdayaan Kesehatan.}

Life skill adalah adanya perubahan yang terjadi dalam diri anggota Pemberdayaan Kesejahteraan Keluarga, salah satu perubahan yang diharapkan yakni perubahan sikap kemandirian dan memotivasi dalam diri dan mengembangkan potensi yang dimiliki oleh para perempuan. Adapun hasil pemberdayaan Life skill yaitu dapat meningkatkan ekonomi keluarga, yang mana anggota Pemberdayaan Kesejahteraan Keluarga telah sukses dalam hasil pemberdayaan Kesejahteraan Keluarga. Dengan keterampilan memasak yang diterapkan yaitu membuat kue bolu, kue basah, kue kering dan berbagai macam kripik, dan lain-lain. ini memiliki penghasilan syang cukup besar dalam proses penjualan.

Pembinaan Rohani yang dilaksanakan Pemberdayaan Kesejahteraan Keluarga dilaksanakan untuk setiap bulannya, seperti yasinan akbar, dan pengajian. Namun sekarang mulai tidak rutin setiap bulannya dikarenakan adanya faktor penghambat dari kegiatan lain masyarakat. Sehingga pembinaan rohani ini masih kurang aktif dalam proses menjalankan kegiatan pembinaan rohani. Pemberdayaan Kesehatan dapat menjalankan pola hidup sehat, yang mana ibu-ibu dapat memberikan asupan gizi yang baik untuk anak-anak mereka. Dan terus mengikuti kegiatan rutin Posyandu Mawar dusun selaparang yang di adakan di halaman rumah salah satu Anggota kader PKK, Sementara para Lansia menjadi lebih semagat untuk menjalankan pola hidup sehat, dan para lansia setiap bulannya untuk ikut melakukan periksa tekanan darah, pemeriksaan kimia darah (kolestrol, gula darah, asam urat), dan sebagainya.

\section{SIMPULAN}

Berdasarkan uraian terdahulu yang penulis teliti dan rangkum dalam sub bab tertentu, maka penulis mengambil beberapa kesimpulan yang terkait tentang Peranan Pemberdayaan Kesejahteraan Keluarga Dalam Meningkatkan Pemberdayaan Perempuan Di Desa Matua Kecamatan Woja Kabupaten Dompu.

1. Pemberdayaan Kesejahteraan Keluarga dalam hal pemberdayaan Life Skill di Desa Matua Kecamatan Woja Kabupaten Dompu, yaitu pertama memberikan bimbingan, Kedua memberikan peralatan, Ketiga, memberikan pelatihan dan keempat melakukan pemasaran.

2. Pemberdayaan Kesejahteraan Keluarga dalam hal pembinaan rohani, Pembinaan rohani dilaksanakan setiap bulannya, yang bertepatan ditanggal 15 sampai dengan 17. Kegiatan yang dilaksanakan yaitu yasinan, dan pengajian rutin. Namun sekarang kegiatan pembinaan rohani sudah mulai tidak aktif dikarenakan adanya kesibukan masyarakat dengan kegiatan mereka masing-masing. Jadi kegiatan yasinan yang awalnya dilakukan setiap bulannya, namun sekarang tidak setiap bulannya dilaksanakan.

3. Pemberdayaan Kesejahteraan Keluarga dalam hal pemberdayaan kesehatan, Pemberdayaan kesehatan dilaksanakan secara rutin setiap bulannya, yaitu setiap tanggal 6. Pemberdayaan kesehatan pada balita yaitu mengadakan penyuntikan untuk usia 0-12 bulan, memberikan susu kepada bailta. Pemberian makanan tambahan (PMT) untuk balita. Sedangkan pada lansia yaitu mengadakan periksa kesehatan, baik keluhan saat diperiksa, tekanan darah, pemeriksaan kimia darah (kolestrol, gula darah, asam urat), dan sebagainya. Posyandu lansia biasanya rutin mengadakan olahraga ringan, yaitu senam sehat yang diadakan setiap hari minggu. Selain itu penyuluhan mengenai pola hidup sehat bagi lansia.

\section{DAFTAR RUJUKAN}

Allison, M., dan Kaye, J. 2004. Perencanaan Strategis Bagi Organisasi Nirlaba. Jakarta: Yayasan Obor Indonesia 
Anita Kustiarini dan dhiah fitrayani. 2004. Strategi pengembangan UKM batu arca di desa watesumpak dalam menghadapi globalisasi. E-joernal UNESA.vol 2.no 3

Arikunto, S (2002). Prosedur penelitian, suatu pendekatan praktek. Jakarta: PT Rineka Cipta.

Kumolo, Tjahjo. 2017. Nawa cita Untuk Kesejahteraan Rakyat Indonesia : Integrasi Perencanaan Nasional dan Daerah. Jakarta : Gramedia .

Muhammad regalfa M (2015)strategi pengembangan usaha kecil dan menengah melalui marketing online oleh dinas koperasi dan UMKM kabupaten banyuwangi.

Pasal 21 dan pasal 27 Undang-Undang Dasar 1945, menjamin adanya kesamaan hak dan kewajiban bagi penduduk tanpa membeda-bedakan

Pearce II, John A. dan Robinson Richard B.Jr. (2008). Manajemen Strategis 10. Salemba Empat : Jakarta

Rangkuti, Freddy. 2006. Analisis SWOT Teknik Membedah Kasus Bisnis. Jakarta: PT. Gramedia Pustaka Utama.

Singarimbun, Masri dan sofian Effendi, 2002. Metode penelitian survai. Jakarta: LP3ES.

Sugiyono, (2008). Metode penelitian kuantitatif kualitatif dan R\&D. Bandung Alfabeta.

Tjiptono, Fandy. 2008. Stretegi Pemasaran. Edisi III.Yogyakarta: CV. Andi Offset

Wheelen, Thomas L dan Hunger, J. David .(2012). Manajemen Strategis. Yogyakarta: Andi 